\title{
Increased Occurrence of Treponema spp. and Double-species Infections in Patients with Alzheimer's Disease
}

Michal Nemergut ${ }^{1,2}$, Tereza Batkova ${ }^{1,3,4}$, Dana Vigasova $^{1,2}$, Milan Bartos ${ }^{4}$, Martina Hlozankova $^{4}$, Andrea Schenkmayerova ${ }^{1,2}$, Barbora Liskova ${ }^{2}$, Katerina Sheardova ${ }^{1,3}$, Martin Vyhnalek $^{1,5}$, Jakub Hort ${ }^{1,5}$, Jan Laczo ${ }^{1,5}$, Ingrid Kovacova ${ }^{1}$, Michal Sitina ${ }^{1}$, Radoslav Matej ${ }^{6}$, Radim Jancalek ${ }^{7}$, Martin Marek ${ }^{1,2}$, Jiri Damborsky ${ }^{1,2 *}$

${ }^{1}$ International Clinical Research Center, St. Anne's University Hospital Brno, Brno, Czech Republic;

${ }^{2}$ Loschmidt Laboratories, Department of Experimental Biology and RECETOX, Masaryk University, Brno, Czech Republic;

${ }^{3}$ Department of Neurology, Masaryk University, St. Anne's University Hospital Brno, Brno, Czech Republic;

${ }^{4}$ BioVendor, Brno, Czech Republic;

5 Department of Neurology, Charles University, Second Faculty of Medicine and Motol University Hospital, Prague, Czech Republic;

${ }^{6}$ Thomayer University Hospital, Prague, Czech Republic;

${ }^{7}$ Department of Neurosurgery, St. Anne's University Hospital Brno, Brno, Czech Republic;

* corresponding author jiri@chemi.muni.cz 


\begin{abstract}
Objective: Although the link between microbial infections and Alzheimer's disease (AD) has been demonstrated in multiple studies, the involvement of pathogens in the development of AD remains unclear. Therefore, this theory beckons further systematic investigation. In this study, we have examined the association between the 10 most widely discussed viral and bacterial pathogens found in serum and cerebrospinal fluid (CSF) from patients with AD.
\end{abstract}

Methods: We have used an in-house developed multiplex PCR kit for simultaneous detection of five bacterial and five viral pathogens in serum and CSF from 50 AD patients and 53 healthy controls. Data analysis was performed with multiple statistical methods: Fisher's exact test, chisquare goodness of fit test, and one-sample proportion test.

Results: We observed an increased frequency of $\mathrm{AD}$ patients tested positive for Treponema spp. (AD: 62.2\%; CTRL: 30.3\%; $p$-value $=0.007$ ). Furthermore, we confirmed a significantly higher prevalence of cases with two and more simultaneous infections in AD patients compared to controls (AD: 24\%; CTRL 7.5\%; $p$-value $=0.029$ ). The studied pathogens were widespread equally in serum and CSF. Borrelia burgdorferi, human herpesvirus 7, and human cytomegalovirus were not detected in any of the studied samples.

Discussion: An increased prevalence of Treponema spp. and double-species infections in AD patients compared to the healthy controls provides further evidence of the association between microbial infections and AD. Paralleled analysis of multiple sample specimens provides complementary information and is advisable for future studies. 


\section{Introduction}

Alzheimer's disease (AD) is an irreversible, progressive neurodegenerative pathology. It accounts for $60-80 \%$ of dementia [1], a general term for memory loss and other cognitive abilities, serious enough to interfere with daily life. The AD aetiology is largely unknown to this day. The most widely accepted hypothesis for AD pathogenesis is the amyloid cascade hypothesis, which states that the cause of $\mathrm{AD}$ is a senile plaque formation by the $\beta$-amyloid peptide and the generation of neurofibrillary tangles of hyperphosphorylated tau protein [2]. However, the reason for the initial accumulation of $\beta$-amyloid is unknown in most patients with sporadic AD [3]. Previous research brought some evidence about the role of infection in AD pathophysiology [4]. AD was linked to infectious agents in the brain tissue, specifically to herpes simplex virus 1 (HSV-1), almost 30 years ago [5]. Ever since then, a growing body of evidence has associated the infection of various other viruses, including human herpesvirus 6 and 7 (HHV-6 and HHV-7) [6-9], human cytomegalovirus (CMV) [9-12] and Epstein-Barr virus (EBV) [7] with the risk of developing AD. Different bacterial species, including Chlamydia pneumoniae [13], Helicobacter pylori [14,15], Borrelia burgdorferi [16], Porphyromonas gingivalis [17] and Treponema spp. [18] were also implicated in AD pathogenesis.

However, the data driving the infectious hypothesis of $\mathrm{AD}$ has been conflicting, causing an inevitable controversy in the field [19]. Although the extent of causal contribution of infections is not conclusive, certain microorganisms could act as accelerants, exacerbating the disease once it is established [19]. Evidence suggests that severe sepsis survivors are more likely to develop substantial and persistent cognitive impairment and functional disability [20]. Moreover, it is unclear whether the disease process involves a single microorganism or several species, acting independently or in combination [19]. Therefore, more research in this field is needed, comparing the data collected from multiple specimen types and involving alternative methods for pathogen detection.

In this study, we developed a new multiplex PCR kit for simultaneous detection of acute inflammation of the 10 most prevalent bacterial and viral pathogens associated with AD. Based on this, we compared the occurrence of single and multiple infections in AD patients and controls. In addition, we compared the prevalence of the studied pathogens between serum and CSF matched AD patients and controls. 


\section{Material and methods}

\section{Study participants}

We have analysed samples from 50 living patients diagnosed with AD by biomarkers in mild cognitive impairment (MCI) or dementia stages (mean age 71 years; 17 males and 33 females) recruited from the Czech Brain Aging Study (CBAS) [21]. They consisted of 5 serum samples and 45 serum and CSF matched samples. All CBAS patients underwent the complex diagnostic process including neuropsychological examination, brain MRI, neurological examination, and routine blood tests. Control samples were obtained from 53 donors (mean age 45 years; 19 males and 34 females). Serum and CSF samples were obtained from 18 CBAS subjects and 27 cognitively healthy subjects undergoing spinal tap for differential diagnosis of headache or facial palsy. They consisted of 9 serum samples, 3 CSF samples and 33 matched CSF and serum samples. To exclude AD pathology, subjects were selected with the following criteria: the subjects had negative AD biomarkers in CSF or were cognitively stable for 3 years of follow up and APOE 4 negative. In the cognitively healthy headache and facial palsy group, only subjects with physiological parameters of CSF were included. Eight brain samples were obtained from the patients undergoing surgery for pharmacoresistant epilepsy. The name of Ethics Committee is FN u sv. Anny v Brne and the approval numbers are 45V/2016 and 46V/2016-AM. All procedures were performed in consistence with Good clinical practice and after signing informed consent.

\section{DNA isolation and PCR primers design}

Samples were thawed and cut into smaller pieces in case of brain tissue. DNA was extracted using RTP Pathogen Kit (STRATEC, USA). Each extract was tested for all ten pathogens by amplifying species-specific gene sequences using species-selective primers. All primers used in this study were designed in-house using the Primer-BLAST tool for finding primers specific to the polymerase chain reaction (PCR) template (Table 1).

Table 1. List of primers (5'-3') used in the polymerase chain reaction.

\begin{tabular}{clll} 
Pathogen & Primer $\mathbf{F}$ & Primer $\mathbf{R}$ & Probe \\
\hline \multirow{2}{*}{ Borrelia burgdorferi } & CTT ATC ACC GGC & GCA TGG TTG TCG & CAA CCC TTG TTA TCT \\
& AGT CTT ATC & TCA GCT CGT GC & GTT ACC AG \\
\hline \multirow{2}{*}{ Chlamydia pneumoniae } & GACC ATC AAT TAT & TGA GCA ATG CGG & CTC TTT AGT GCC ATA \\
& CAT GAA TGG & ATG TTA TCA & CAT TGG AG \\
\hline \multirow{2}{*}{ Helicobacter pylori } & GAA ACG ATG ATT & CAG GCC GGA TAC & AGG ACA TAG GCT GAT C \\
& AAT ACC AGA TAC & CCG TCA TAG & TC TTA GCG ATA AAT CTT \\
& TCC C & & \\
\hline
\end{tabular}




\begin{tabular}{clll}
\hline \multirow{2}{*}{ Porphyromonas gingivalis } & $\begin{array}{l}\text { CAGCATGATCTTAG } \\
\text { CTTGCTAAG }\end{array}$ & $\begin{array}{l}\text { AGTCCGTCTTTCAA } \\
\text { CGGGTTA }\end{array}$ & $\begin{array}{l}\text { CGCACCCGTGCGCCGGTC } \\
\text { GCCATC- }\end{array}$ \\
\hline \multirow{2}{*}{ Treponema spp. } & CGA GRA ACC TTA & TAA CCC AAC ACC & AGG TGC TGC ATG GCT G \\
& CCT GGG TTT & TCA CGG CA & TC GT \\
\hline \multirow{2}{*}{ Cytomegalovirus } & GAT CTG CAT GAA & GGT GAC ACC AGA & G ATC CTC TGA GAG TCT \\
& GGT CTT TGC & GAA TCA G & GCT CTC C \\
\hline \multirow{2}{*}{ Epstein-Barr virus } & TCC ACA ATG TCG & ACA GAC AAT GGA & TG GCC CCT GGA CCC \\
& TA/CT TAC ACC & CTC CCT TA & GGC \\
\hline \multirow{2}{*}{ Herpes simplex virus 1 } & CCA CCT CCT & AGC TTG CGG GCC & G CAA CGC GGC CCA ACA \\
& CC/GA TCG AGT T & TCG TTC C & TAT C \\
\hline \multirow{2}{*}{ Human herpesvirus 6 } & GAA GCA GCA ATC & ACA ACA TGT AAC & AC CCG TGC GCC GCT CC \\
& GCA ACA C & TCG GTG TAC GG & \\
\hline \multirow{2}{*}{ Human herpesvirus 7 } & CCC AAC TAT TTA & TTT AGT TCC AGC & CTA TTT TCG GTC TTT CC \\
& CAG TAG GGT TGG & ACT GCA ATC G & A ATG CAC GCA \\
& TG & & \\
\hline
\end{tabular}

\section{Polymerase chain reaction}

Multiplex PCR for detecting five bacterial species Chlamydia pneumoniae, Helicobacter pylori, Borrelia burgdorferi, Porphyromonas gingivalis, Treponema spp., and five viral species HSV-1, EBV, HHV-6, HHV-7, CMV, was developed. The PCR MasterMixes of $20 \mu \mathrm{l}$ contained $2 \mathrm{U}$ of Taq polymerase (Thermofisher Scientific, United Kingdom) and $2 \mathrm{U}$ of Uracil-D-glycosylase (New England Biolabs, USA). Conditions of PCR were as follows: incubation for $2 \mathrm{~min}$ at $37^{\circ} \mathrm{C}$ to perform deactivation of old amplicons by Uracil-D-glycosylase, activation for $15 \mathrm{~min}$ at $95^{\circ} \mathrm{C}, 45$ cycles of denaturation, each $5 \mathrm{~s}$ at $95^{\circ} \mathrm{C}$, annealing for $40 \mathrm{~s}$ at $60^{\circ} \mathrm{C}$ and polymerisation for $20 \mathrm{~s}$ at $72^{\circ} \mathrm{C}$. A positive signal was read in the FAM channel and a signal for internal control in the HEX/JOE channel. Each PCR experiment included either AD or control DNA, a positive DNA template, and a no-DNA control. A subject was considered positive for a given species if the extract contained a positive signal with $\mathrm{Ct} \leq 35.0$. Positive controls were performed using plasmid vectors carrying loci for respective pathogens. Reagents and disposable supplies were examined for DNA as the negative controls. All tests were successfully validated using international panels available on a regular basis from INSTAND, e.V. (Germany).

\section{Statistical analysis}

Statistical methods used for data analysis included Fisher's exact test, chi-square goodness of fit test and one-sample proportion test. The significance of the difference between $\mathrm{AD}$ patients and controls was determined by Fisher's exact test. The chi-square goodness of fit test was used to assess the differences in the distribution of the prevalence of cases without infection, with single infection and multiple infections. Differences between individual groups 
were further analysed using a one-sample proportion test with Bonferroni correction for multiple testing. All statistical analyses were performed using the software R (version 4.0.4). $P$-values less than 0.05 were considered statistically significant.

\section{Results}

\section{Comparison of bacterial and viral infections between AD patients and controls}

To investigate the possible association between increased bacterial/viral infections and $\mathrm{AD}$, we divided all $\mathrm{AD}$ patients and controls into four groups: group 1 - tested positive for at least one pathogen; group 2 - tested negative for all studied pathogens; group 3 - tested positive for a single pathogen; group 4 - simultaneously tested positive for two or more pathogens. The data from $50 \mathrm{AD}$ patients and 53 controls, which were tested positive for at least one bacterial or viral pathogen, are compared in Figure 1.

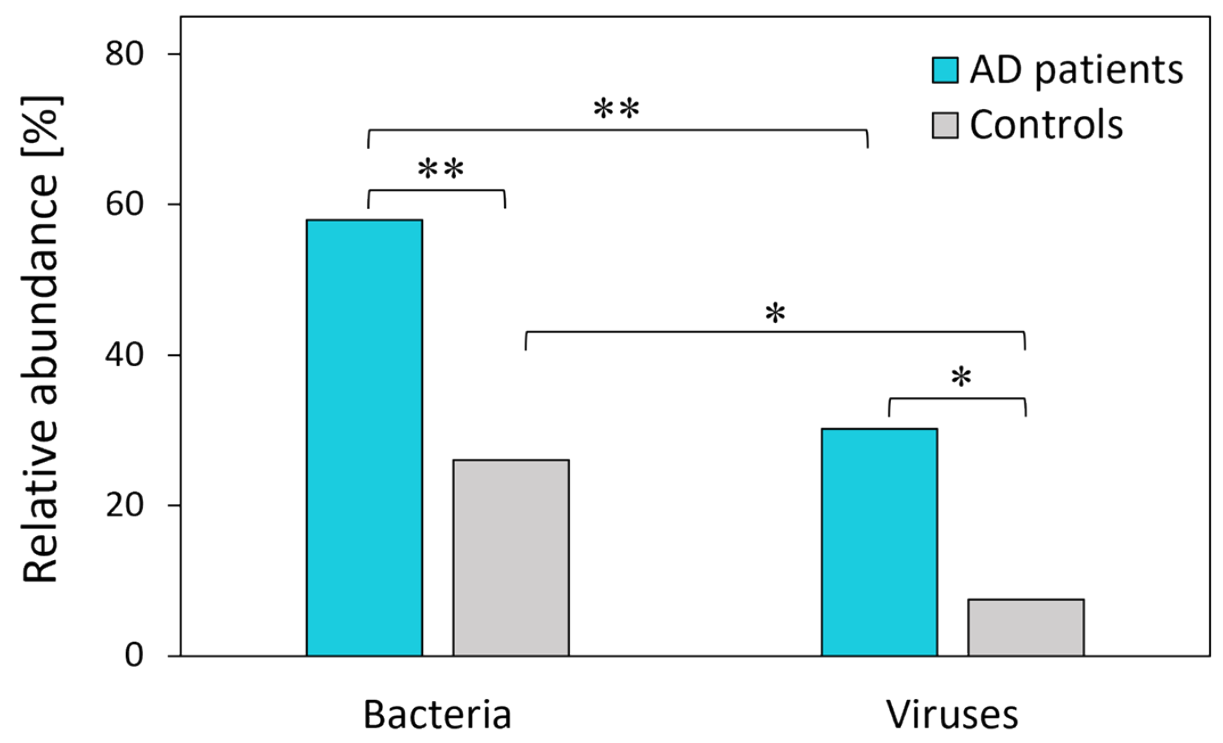

Figure 1. Percentage of AD patients (turquoise) and controls (grey) with at least one bacterial or viral pathogen detected. Asterisks represent statistical significance $(* p$-value $\leq 0.05 ; * * p$ value $\leq 0.01)$.

Our results showed a significant difference between $\mathrm{AD}$ patients and controls in the prevalence of both bacterial $(p$-value $=0.006)$ and viral $(p$-value $=0.016)$ pathogens $($ Table 2$)$. In group 1, almost twice as many $\mathrm{AD}$ patients $(58 \%)$ were positive for bacterial infection compared to controls (30.2\%). Similarly, the frequency of viral pathogens was 3.5 times higher 
in $\mathrm{AD}$ patients (26\%) than in controls $(7.5 \%)$. No significant difference in the prevalence of bacterial and viral pathogens was found in studied groups in terms of gender. A comparison of bacterial and viral prevalence revealed that the bacterial pathogens are present in a significantly higher proportion than viral pathogens in $\mathrm{AD}$ patients $(p$-value $=0.006)$ as well as the control group $(p$-value $=0.016)$. The prevalence of cases without infection, with single infection and with multiple infections (two and more) is compared in Figure 2.

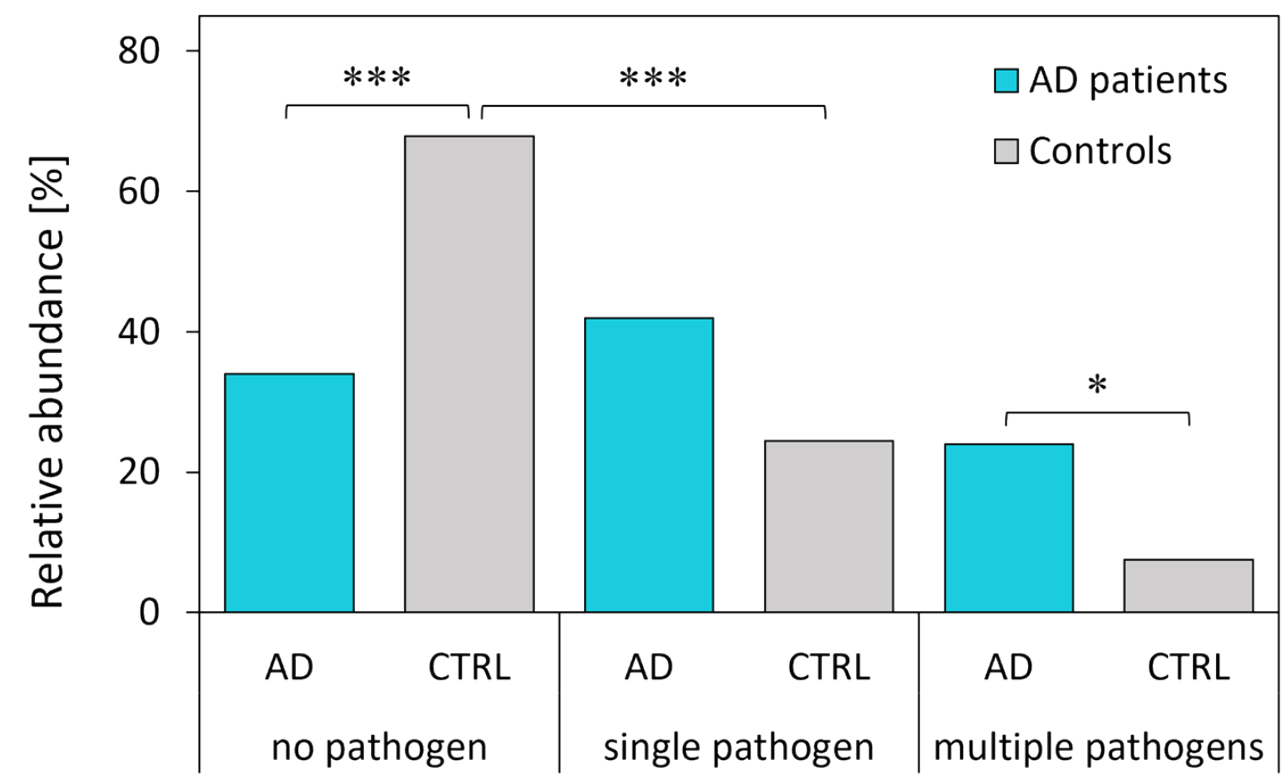

Figure 2. Number of pathogens simultaneously detected in AD patients (turquoise) and controls (grey). Asterisks represent statistical significance $(* p$-value $\leq 0.05 ; * * *$-value $\leq 0.001)$.

Based on the Chi-square goodness of fit test, the distribution of the groups is equal among AD patients ( $p$-value $=0.295)$ while it is unequal among the controls $(p$-value $<0.001)$. The most prevalent group among the controls is the one that tested negative for all studied pathogens (Table 2). As expected, the controls without any pathogen represent $67.9 \%$ of all controls, and their prevalence is significantly higher compared to $34 \%$ of AD patients in the same group ( $p$-value $\leq 0.001)$. The number of AD patients in group $3(42 \%)$ exceeds the number of controls (24.5\%) infected with a single bacterial or viral pathogen; however, this difference is not statistically significant ( $p$-value $=0.093$ ). Interestingly, simultaneous infection by two and more different pathogens was detected in $24 \%$ of AD patients. This represents a significant prevalence compared to controls where the multiple infections were detected only in $7.5 \%$ of controls $(p$-value $=0.029)$.

Table 2. Percentages of AD patients and controls tested positive for bacterial or viral infections. 


\begin{tabular}{|c|c|c|c|c|}
\hline \multicolumn{2}{|c|}{ Pathogens } & $\begin{array}{c}\text { AD patients } \\
(\mathrm{n}=50)\end{array}$ & $\begin{array}{c}\text { Controls } \\
(\mathrm{n}=53)\end{array}$ & $p$-values \\
\hline \multirow{2}{*}{$\begin{array}{c}\text { At least one } \\
\text { pathogen }\end{array}$} & Total & $66 \%$ & $32.1 \%$ & $<0.001$ \\
\cline { 2 - 5 } & Bacteria & $58 \%$ & $30.2 \%$ & 0.006 \\
\cline { 2 - 5 } $\begin{array}{c}\text { No } \\
\text { pathogen }\end{array}$ & Total & $34 \%$ & $67.5 \%$ & 0.016 \\
\hline $\begin{array}{c}\text { Single } \\
\text { pathogen }\end{array}$ & Total & $42 \%$ & $24.5 \%$ & 0.093 \\
\hline $\begin{array}{c}\text { Multiple } \\
\text { pathogens }\end{array}$ & Total & $24 \%$ & $7.5 \%$ & 0.029 \\
\hline
\end{tabular}

\section{Comparison of the prevalence of studied pathogens in serum and CSF}

To explore the prevalence of studied viral and bacterial pathogens in different specimen types, we compared serum, and CSF matched AD patients and controls. The data from $45 \mathrm{AD}$ patients and 33 controls, whoch were tested positive for at least one bacterial or viral pathogen, are compared in Figure 3.

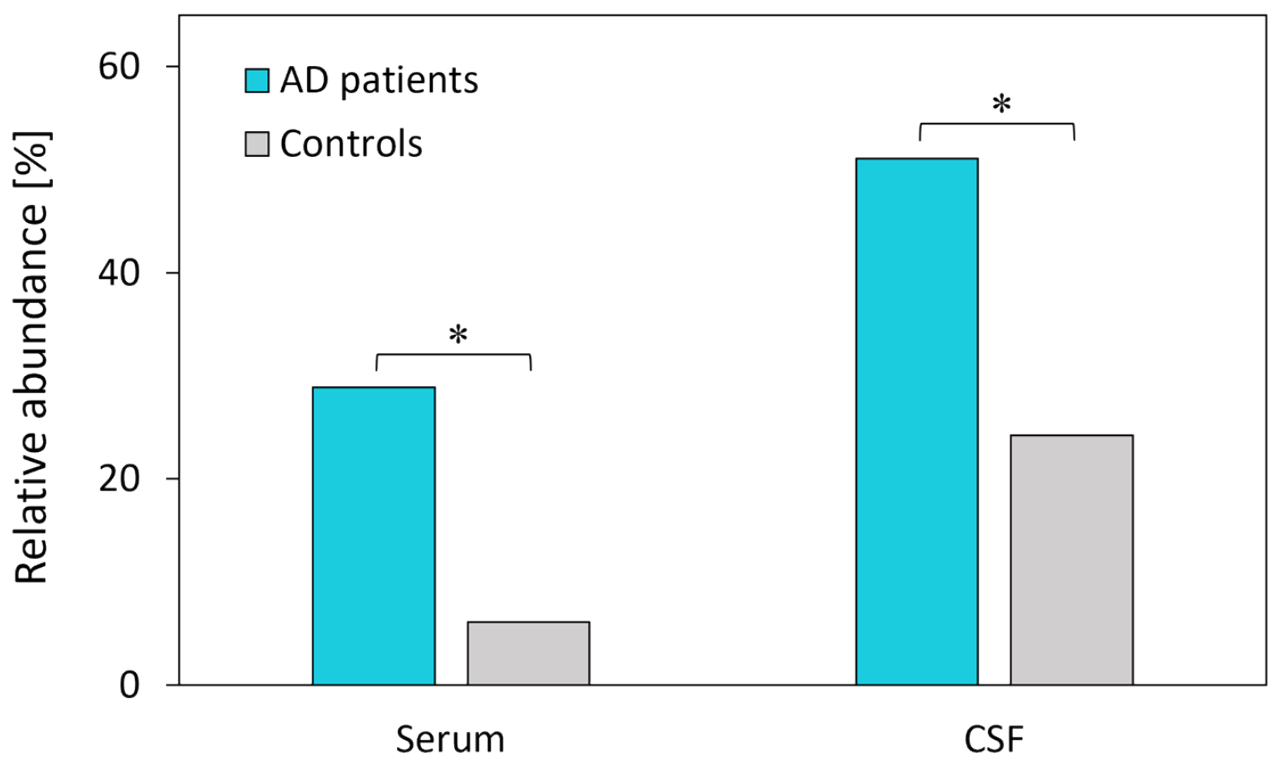

Figure 3. Comparison of serum and CSF matched AD patients (turquoise) and controls (grey) tested positive for at least one pathogen categorized by specimen type. Asterisks represent statistical significance $(* p$-value $\leq 0.05)$.

Similarly, as in the case with all studied subjects, the results showed a significantly higher prevalence of pathogens among AD patients than controls (Table 3). The pathogens were found 
with a higher frequency in CSF than in serum; however, this difference is not considered statistically significant $(\mathrm{AD}: p$-value $=0.052 ; \mathrm{CTRL}: p$-value $=0.082)$. Among AD patients, $51.1 \%$ had at least one pathogen in CSF, $28.9 \%$ had at least one pathogen in serum, and $17.7 \%$ had at least one pathogen in both CSF and serum. In the control group, $24.2 \%$ of controls were tested positive for at least one pathogen in CSF, and 6.1\% were tested positive for at least one pathogen in serum. None of the controls was tested positive for any pathogen in CSF and serum at the same time.

Table 3. Percentages of AD patients and controls tested positive for at least one pathogen in serum and CSF.

\begin{tabular}{|c|c|c|c|}
\hline $\begin{array}{c}\text { Specimen } \\
\text { type }\end{array}$ & $\begin{array}{c}\text { AD patients } \\
(\mathrm{n}=45)\end{array}$ & $\begin{array}{c}\text { Controls } \\
(\mathrm{n}=33)\end{array}$ & $p$-value \\
\hline Serum & $28.9 \%$ & $6.1 \%$ & 0.018 \\
\hline CSF & $51.1 \%$ & $24.2 \%$ & 0.020 \\
\hline p-value & 0.052 & 0.082 & \\
\hline
\end{tabular}

The relative prevalence of individual bacteria and viruses detected in serum and CSF matched AD patients and controls is shown in Figure 4.

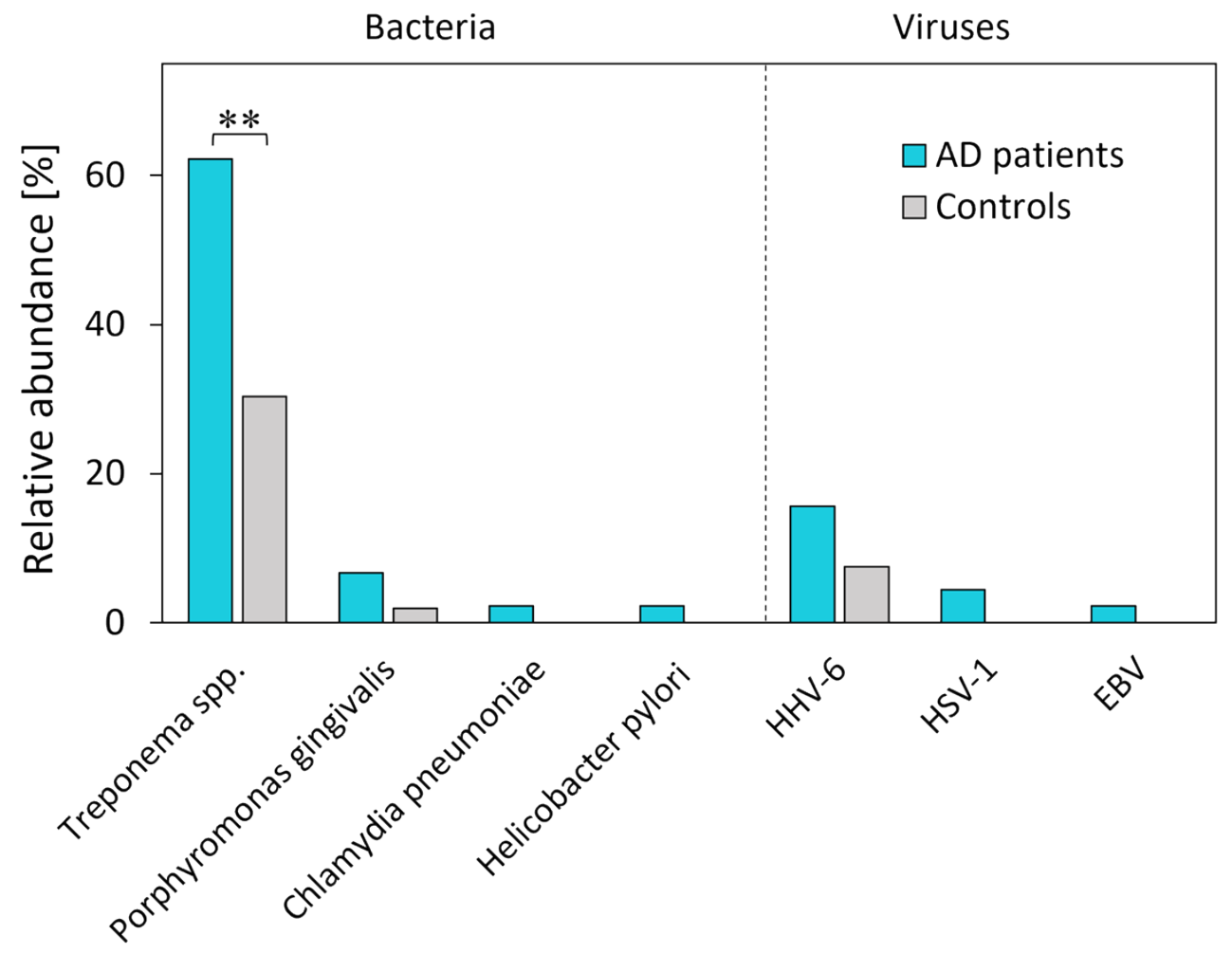


Figure 4. Prevalence of bacterial and viral pathogens between AD patients (turquoise) and controls (grey). Asterisks represent statistical significance $(* * p$-value $\leq 0.01)$.

Our results showed that Treponema spp. is the most prevalent pathogen among AD patients $(62.2 \%)$ as well as controls $(30.3 \%)$. Moreover, it is the only pathogen found in significantly higher prevalence in AD patients compared to controls $(p=0.007)$. Although significantly less prevalent than Treponema spp., the next two pathogens detected in both AD patients and controls are Porphyromonas gingivalis and HHV-6. Porphyromonas gingivalis was detected in $6.7 \%$ of $\mathrm{AD}$ patients and $3.0 \%$ of controls ( $p$-value $=0.634$ ). HHV-6 represents the most prevalent viral pathogen, however, its prevalence among $\mathrm{AD}$ patients (15.6\%) compared to controls $(6.1 \%)$ is not significantly different $(p$-value $=0.062)$. Borrelia burgdorferi, HHV-7, and CMV were detected neither in AD patients nor in the control group. The prevalence of all studied pathogens among $\mathrm{AD}$ patients and controls with corresponding $p$-values is listed in Table 4.

Table 4. The prevalence of individual pathogens among AD patients and controls.

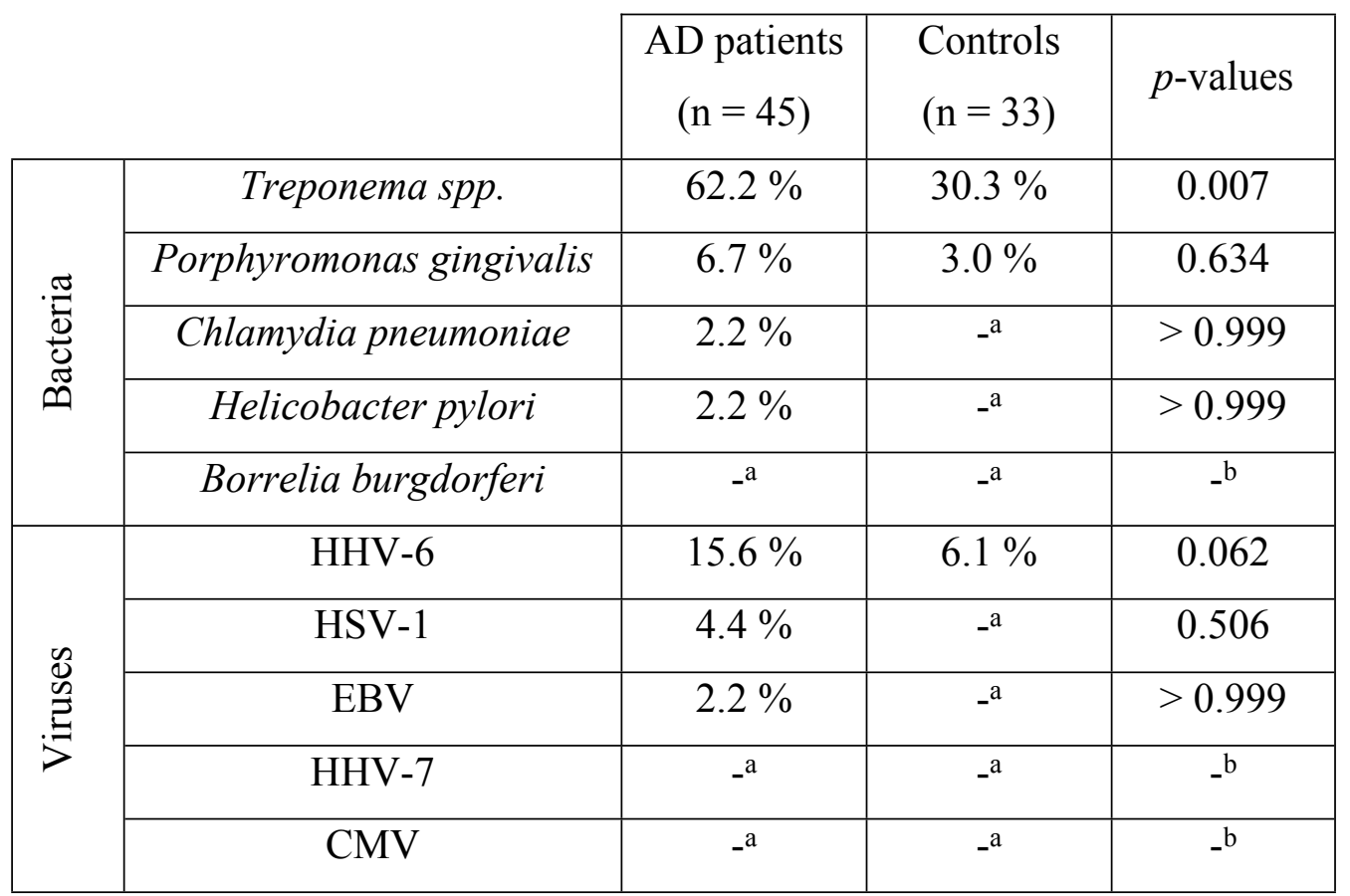

${ }^{a}$ pathogens were not detected in these samples; ${ }^{b}$ not applicable.

Since the occurrence of most studied pathogens is low, there is not a significant difference in the prevalence of any of the studied pathogens in a specific specimen type. Among AD patients, the presence of Treponema spp. was confirmed in $40 \%$ of cases in CSF and $22.2 \%$ of cases in serum $(p=0.110)$. In the control group, Treponema spp. was found in $24.2 \%$ and $6.1 \%$ of CSF and serum samples, respectively $(p=0.082)$. The prevalence of Porphyromonas 
gingivalis was equal among $\mathrm{AD}$ patients and controls in both serum (AD: 2.2\%; CTRL: 0\%) and CSF (AD: 4.4\%; CTRL: 3.0\%). HHV-6 was detected in a higher frequency in CSF compared to serum in both $\mathrm{AD}$ patients and controls. Among AD patients, it was found in $13.3 \%$ of CSF and $2.2 \%$ of serum samples ( $p$-value $=0.110$ ). The prevalence of HHV-6 in the control group was $6.1 \%$ in CSF and no case was found in serum $(p$-value $=0.492)$.

\section{Discussion}

There is accumulating experimental evidence suggesting the connection between microbial infections and the development of $\mathrm{AD}[22,23]$. In the past, most research in this area has focused on individual pathogens, recently reviewed by Sochocka [24]. However, a growing number of research articles (Table 5) suggest that the aetiology of Alzheimer's disease could be driven by the coinfection of multiple pathogens [25]. On the other hand, almost all these studies used serum pathogen-specific antibodies to identify infection burden. Therefore, it could not be determined, if the pathogen specific-antibodies result from current, past, or chronic infections. In this work, we used an in-house PCR kit which allows for simultaneous detection of five bacterial pathogens (Borrelia burgdorferi, Chlamydia pneumoniae, Helicobacter pylori, Porphyromonas gingivalis, and Treponema spp.) and five viral pathogens (CMV, EBV, HHV6, HHV-7, and HSV-1) in serum and CSF samples. Moreover, previously conducted studies targeted only a single specimen type - serum - while parallel analysis of CSF carried out in this study could increase the relevance of collected data.

Our results revealed that both bacteria and viruses are significantly more prevalent in AD-affected samples compared to control samples. This observation is in agreement with recent studies that confirmed an increased bacterial and viral burden in AD patients [26-28]. On the other hand, the cumulative viral and bacterial effect on cognition was not always confirmed [29]. Strandberg et al., who tested seropositivity towards HSV-1, HSV-2, CMV, Chlamydia pneumoniae, and Mycoplasma pneumoniae in the elderly Finnish population, observed a positive correlation between viral burden and cognitive impairment; however, no association with bacterial burden was observed [30,31]. Conversely, the results of our study showed a significantly higher frequency of bacterial infections than viral infections. This discrepancy can be due to our study's different and broader range of studied bacteria compared to the studies mentioned above. We observed a significant increase in the prevalence of Treponema spp. ( $p$ value $=0.082$ ). However, no significant difference in the prevalence was found when comparing the serum and CSF. This observation points to the importance of analysing multiple specimen types in parallel whenever possible. 
bioRxiv preprint doi: https://doi org/10.1101/2021.11.04 467230; this version posted November 5,2021 . The copyright holder for this preprint (which was not certified by peer review) is the author/funder, who has granted bioRxiv a license to display the preprint in perpetuity. It is made available under aCC-BY 4.0 International license.

Table 5. Studies investigating the association of viral and bacterial pathogens with $A D$ and cognitive function (cohort studies).

\begin{tabular}{|c|c|c|c|c|c|c|}
\hline \multirow{2}{*}{ Reference } & \multicolumn{2}{|c|}{ Pathogens } & \multirow{2}{*}{$\begin{array}{l}\text { Specimen } \\
\text { type }\end{array}$} & \multirow{2}{*}{$\begin{array}{c}\text { Sample } \\
\text { size }\end{array}$} & \multirow{2}{*}{$\begin{array}{l}\text { Diagnostic } \\
\text { method }\end{array}$} & \multirow{2}{*}{$\begin{array}{c}\text { Increased } \\
\text { infection } \\
\text { burden }\end{array}$} \\
\hline & Bacteria & Viruses & & & & \\
\hline $\begin{array}{l}\text { Renvoize et } \\
\text { al., } 1987 \\
\text { [29] }\end{array}$ & $\begin{array}{c}\text { Chlamydia Group B, } \\
\text { Coxiella burnettii, } \\
\text { Measles, } \\
\text { Mycoplasma } \\
\text { pneumoniae }\end{array}$ & $\begin{array}{c}\text { HSV-1, } \\
\text { CMV, } \\
\text { Adenovirus, } \\
\text { Influenza } \\
\text { A and B }\end{array}$ & Serum & $\begin{array}{c}\text { AD: } 33 \\
\text { CTRL: } 28\end{array}$ & $\begin{array}{l}\text { Complement } \\
\text { fixation test }\end{array}$ & none \\
\hline $\begin{array}{c}\text { Strandberg } \\
\text { et al., } 2003 \\
{[30]}\end{array}$ & $\begin{array}{l}\text { Chlamydia } \\
\text { pneumoniae, } \\
\text { Mycoplasma } \\
\text { pneumoniae }\end{array}$ & $\begin{array}{l}\text { HSV-1, } \\
\text { HSV-2, } \\
\text { CMV }\end{array}$ & Serum & $\begin{array}{l}\text { Cohort } \\
\text { study }\end{array}$ & ELISA & Viruses \\
\hline $\begin{array}{c}\text { Strandberg } \\
\text { et al., } 2005 \\
{[31]}\end{array}$ & $\begin{array}{c}\text { Chlamydia } \\
\text { pneumoniae, } \\
\text { Helicobacter pylori, } \\
\text { Mycoplasma } \\
\text { pneumoniae, }\end{array}$ & $\begin{array}{l}\text { HSV-1, } \\
\text { HSV-2, } \\
\text { CMV }\end{array}$ & Serum & $\begin{array}{l}\text { Cohort } \\
\text { study }\end{array}$ & ELISA & Viruses \\
\hline $\begin{array}{c}\text { Katan et al., } \\
2013 \text { [26] }\end{array}$ & $\begin{array}{c}\text { Chlamydia } \\
\text { pneumoniae, } \\
\text { Helicobacter pylori }\end{array}$ & $\begin{array}{l}\text { HSV-1, } \\
\text { HSV-2, } \\
\text { CMV }\end{array}$ & Serum & $\begin{array}{l}\text { Cohort } \\
\text { study }\end{array}$ & ELISA & $\begin{array}{l}\text { Bacteria } \\
\text { \& Viruses }\end{array}$ \\
\hline $\begin{array}{l}\text { Bu et al., } \\
2014 \text { [27] }\end{array}$ & $\begin{array}{c}\text { Borrelia burgdorferi, } \\
\text { Chlamydia } \\
\text { pneumoniae, } \\
\text { Helicobacter pylori }\end{array}$ & $\begin{array}{l}\text { HSV-1, } \\
\text { CMV }\end{array}$ & Serum & $\begin{array}{c}\text { AD: } 128 \\
\text { CTRL: } 135\end{array}$ & ELISA & $\begin{array}{l}\text { Bacteria } \\
\text { \& Viruses }\end{array}$ \\
\hline $\begin{array}{l}\text { Wright et } \\
\text { al., } 2015 \\
{[28]}\end{array}$ & $\begin{array}{c}\text { Chlamydia } \\
\text { pneumoniae, } \\
\text { Helicobacter pylori }\end{array}$ & $\begin{array}{l}\text { HSV-1, } \\
\text { HSV-2, } \\
\text { CMV }\end{array}$ & Serum & $\begin{array}{l}\text { Cohort } \\
\text { study }\end{array}$ & ELISA & $\begin{array}{l}\text { Bacteria } \\
\& \text { Viruses }\end{array}$ \\
\hline This study & $\begin{array}{c}\text { Borrelia } \\
\text { burgdorferi, } \\
\text { Chlamydia } \\
\text { pneumoniae, } \\
\text { Helicobacter pylori, } \\
\text { Porphyromonas } \\
\text { gingivalis, } \\
\text { Treponema spp. }\end{array}$ & $\begin{array}{l}\text { CMV, } \\
\text { EBV, } \\
\text { HSV-1, } \\
\text { HHV-6, } \\
\text { HHV-7 }\end{array}$ & $\begin{array}{c}\text { Serum } \\
\text { CSF }\end{array}$ & $\begin{array}{c}\text { AD: } \mathbf{5 0} \\
\text { CTRL: } \mathbf{5 3}\end{array}$ & PCR & $\begin{array}{l}\text { Bacteria } \\
\text { \& Viruses }\end{array}$ \\
\hline
\end{tabular}

Interestingly, all tested samples in this study were negative for Borrelia burgdorferi, HHV-7 and CMV despite these pathogens having been linked to AD in previous studies $[6,10,32-35]$. Although, the direct role of CMV in the causation of AD is thought to be unlikely [36]. Our results further confirmed a significantly higher prevalence of cases with multiple (two and more) infections in AD patients compared to controls (AD: 24\%; CTRL: 7.5\%). Moreover, while the prevalence of $\mathrm{AD}$ patients without infection, single infection, and multiple infections is comparable, there is a significant difference in the prevalence of controls without infection and with infection. In addition, a significant difference between AD patients and control tested 
negative for all studied pathogens (AD: 34\%; CTRL: 67.9\%) strongly supports a positive correlation between infectious burden and AD. However, the limitation of the present study is the fact that the samples could not be obtained for the age-matched subjects. This is very challenging, particularly for the samples of brains tissues. Further investigations are needed to confirm the impact of microbial infections on $\mathrm{AD}$ using the samples for age-matched $\mathrm{AD}$ patients and controls.

In summary, to the best of our knowledge, our study is the most comprehensive analysis in terms of detection method, pathogen range, and specimen types conducted thus far. Our results convincingly show that both bacteria and viruses are significantly more prevalent in $A D$ patients than in controls.

\section{Author contributions}

$\mathrm{MN}$ - writing of the manuscript, data analysis, interpretation; TB - testing of samples and data analysis; DV - development of assays, data collection; AS - data analysis; MB - development of assays, data analysis, interpretation, supervision; $\mathrm{MH}$ - development of assays, supervision; $\mathrm{BL}$ - data collection; KS - a collection of clinical samples, interpretation; $\mathrm{MV}$ - a collection of clinical samples, interpretation; JH - a collection of clinical samples, interpretation; JL - a collection of clinical samples, interpretation; IK - statistical analysis; MS - statistical analysis, interpretation; RM - a collection of clinical samples, interpretation; RJ - a collection of clinical samples, interpretation; MM - supervision, funding; JD - experimental design, data interpretation, funding; All co-authors contributed to the revisions of the manuscript.

\section{Acknowledgements}

The authors would like to express their thanks to the Ministry of Education of the Czech Republic (INBIO - $\quad$ CZ.02.1.01/0.0/0.0/16_026/0008451; $\quad$ ENOCH CZ.02.1.01/0.0/0.0/16_019/0000868), Technology Agency of the Czech Republic (Permed TN01000013) and Masaryk University (MUNI/H/1561/2018) for the financial support.

\section{References}

[1] 2021 Alzheimer's disease facts and figures. Alzheimers Dement 2021;17:327-406. https://doi.org/10.1002/alz.12328.

[2] Hardy J, Selkoe DJ. The Amyloid Hypothesis of Alzheimer's Disease: Progress and Problems on the Road to Therapeutics. Science 2002;297:353-6. https://doi.org/10.1126/science.1072994. 
bioRxiv preprint doi: https://doi.org/10.1101/2021.11.04.467230; this version posted November $5,2021$. The copyright holder for this preprint (which was not certified by peer review) is the author/funder, who has granted bioRxiv a license to display the preprint in perpetuity. It is made available under aCC-BY 4.0 International license.

[3] Paroni G, Bisceglia P, Seripa D. Understanding the Amyloid Hypothesis in Alzheimer's Disease. J Alzheimers Dis JAD 2019;68:493-510. https://doi.org/10.3233/JAD-180802.

[4] Fulop T, Witkowski JM, Bourgade K, Khalil A, Zerif E, Larbi A, et al. Can an Infection Hypothesis Explain the Beta Amyloid Hypothesis of Alzheimer's Disease? Front Aging Neurosci 2018;10. https://doi.org/10.3389/fnagi.2018.00224.

[5] Jamieson GA, Maitland NJ, Wilcock GK, Craske J, Itzhaki RF. Latent herpes simplex virus type 1 in normal and Alzheimer's disease brains. J Med Virol 1991;33:224-7. https://doi.org/10.1002/jmv.1890330403.

[6] Readhead B, Haure-Mirande J-V, Funk CC, Richards MA, Shannon P, Haroutunian V, et al. Multiscale Analysis of Independent Alzheimer's Cohorts Finds Disruption of Molecular, Genetic, and Clinical Networks by Human Herpesvirus. Neuron 2018;99:6482.e7. https://doi.org/10.1016/j.neuron.2018.05.023.

[7] Carbone I, Lazzarotto T, Ianni M, Porcellini E, Forti P, Masliah E, et al. Herpes virus in Alzheimer's disease: relation to progression of the disease. Neurobiol Aging 2014;35:122-9. https://doi.org/10.1016/j.neurobiolaging.2013.06.024.

[8] Hemling N, Röyttä M, Rinne J, Pöllänen P, Broberg E, Tapio V, et al. Herpesviruses in brains in Alzheimer's and Parkinson's diseases. Ann Neurol 2003;54:267-71. https://doi.org/10.1002/ana.10662.

[9] Lin W-R, Wozniak MA, Cooper RJ, Wilcock GK, Itzhaki RF. Herpesviruses in brain and Alzheimer's disease. J Pathol 2002;197:395-402. https://doi.org/10.1002/path.1127.

[10] Barnes LL, Capuano AW, Aiello AE, Turner AD, Yolken RH, Torrey EF, et al. Cytomegalovirus Infection and Risk of Alzheimer Disease in Older Black and White Individuals. J Infect Dis 2015;211:230-7. https://doi.org/10.1093/infdis/jiu437.

[11] Lövheim H, Olsson J, Weidung B, Johansson A, Eriksson S, Hallmans G, et al. Interaction between Cytomegalovirus and Herpes Simplex Virus Type 1 Associated with the Risk of Alzheimer's Disease Development. J Alzheimers Dis JAD 2018;61:939-45. https://doi.org/10.3233/JAD-161305.

[12] Carbone I, Lazzarotto T, Ianni M, Porcellini E, Forti P, Masliah E, et al. Herpes virus in Alzheimer's disease: relation to progression of the disease. Neurobiol Aging 2014;35:122-9. https://doi.org/10.1016/j.neurobiolaging.2013.06.024.

[13] Balin BJ, Hammond CJ, Little CS, Hingley ST, Al-Atrache Z, Appelt DM, et al. Chlamydia pneumoniae: An Etiologic Agent for Late-Onset Dementia. Front Aging Neurosci 2018;10. https://doi.org/10.3389/fnagi.2018.00302.

[14] Kountouras J, Boziki M, Gavalas E, Zavos C, Deretzi G, Grigoriadis N, et al. Increased Cerebrospinal Fluid Helicobacter Pylori Antibody in Alzheimer's Disease. Int J Neurosci 2009;119:765-77. https://doi.org/10.1080/00207450902782083.

[15] Beydoun MA, Beydoun HA, Weiss J, Hossain S, El-Hajj ZW, Zonderman AB. Helicobacter pylori , periodontal pathogens, and their interactive association with incident all-cause and Alzheimer's disease dementia in a large national survey. Mol Psychiatry 2020:1-16. https://doi.org/10.1038/s41380-020-0736-2.

[16] Miklossy J. Bacterial Amyloid and DNA are Important Constituents of Senile Plaques: Further Evidence of the Spirochetal and Biofilm Nature of Senile Plaques. J Alzheimers Dis n.d.;53:1459-73. https://doi.org/10.3233/JAD-160451.

[17] Dominy SS, Lynch C, Ermini F, Benedyk M, Marczyk A, Konradi A, et al. Porphyromonas gingivalis in Alzheimer's disease brains: Evidence for disease causation and treatment with small-molecule inhibitors. Sci Adv 2019;5. https://doi.org/10.1126/sciadv.aau3333.

[18] Riviere GR, Riviere KH, Smith KS. Molecular and immunological evidence of oral Treponema in the human brain and their association with Alzheimer's disease. Oral Microbiol Immunol 2002;17:113-8. https://doi.org/10.1046/j.0902-0055.2001.00100.x. 
bioRxiv preprint doi: https://doi.org/10.1101/2021.11.04.467230; this version posted November 5, 2021. The copyright holder for this preprint (which was not certified by peer review) is the author/funder, who has granted bioRxiv a license to display the preprint in perpetuity. It is made available under aCC-BY 4.0 International license.

[19] Itzhaki RF, Golde TE, Heneka MT, Readhead B. Do infections have a role in the pathogenesis of Alzheimer disease? Nat Rev Neurol 2020;16:193-7. https://doi.org/10.1038/s41582-020-0323-9.

[20] Iwashyna TJ, Ely EW, Smith DM, Langa KM. Long-term Cognitive Impairment and Functional Disability Among Survivors of Severe Sepsis. Jama 2010;304:1787-94. https://doi.org/10.1001/jama.2010.1553.

[21] Sheardova K, Vyhnalek M, Nedelska Z, Laczo J, Andel R, Marciniak R, et al. Czech Brain Aging Study (CBAS): prospective multicentre cohort study on risk and protective factors for dementia in the Czech Republic. BMJ Open 2019;9:e030379. https://doi.org/10.1136/bmjopen-2019-030379.

[22] Panza F, Lozupone M, Solfrizzi V, Watling M, Imbimbo BP. Time to test antibacterial therapy in Alzheimer's disease. Brain 2019;142:2905-29. https://doi.org/10.1093/brain/awz244.

[23] Fülöp T, Munawara U, Larbi A, Desroches M, Rodrigues S, Catanzaro M, et al. Targeting Infectious Agents as a Therapeutic Strategy in Alzheimer's Disease. CNS Drugs 2020. https://doi.org/10.1007/s40263-020-00737-1.

[24] Sochocka M, Zwolińska K, Leszek J. The Infectious Etiology of Alzheimer's Disease. Curr Neuropharmacol 2017;15:996-1009. https://doi.org/10.2174/1570159X15666170313122937.

[25] Vigasova D, Nemergut M, Liskova B, Damborsky J. Multi-pathogen infections and Alzheimer's disease. Microb Cell Factories 2021;20:25. https://doi.org/10.1186/s12934021-01520-7.

[26] Katan M, Moon YP, Paik MC, Sacco RL, Wright CB, Elkind MSV. Infectious burden and cognitive function: the Northern Manhattan Study. Neurology 2013;80:1209-15. https://doi.org/10.1212/WNL.0b013e3182896e79.

[27] Bu X-L, Yao X-Q, Jiao S-S, Zeng F, Liu Y-H, Xiang Y, et al. A study on the association between infectious burden and Alzheimer's disease. Eur J Neurol 2015;22:1519-25. https://doi.org/10.1111/ene.12477.

[28] Wright CB, Gardener H, Dong C, Yoshita M, DeCarli C, Sacco RL, et al. Infectious Burden and Cognitive Decline in the Northern Manhattan Study. J Am Geriatr Soc 2015;63:1540-5. https://doi.org/10.1111/jgs.13557.

[29] Renvoize EB, Awad IO, Hambling MH. A sero-epidemiological study of conventional infectious agents in Alzheimer's disease. Age Ageing 1987;16:311-4.

[30] Strandberg TE, Pitkala KH, Linnavuori KH, Tilvis RS. Impact of viral and bacterial burden on cognitive impairment in elderly persons with cardiovascular diseases. Stroke 2003;34:2126-31. https://doi.org/10.1161/01.STR.0000086754.32238.DA.

[31] Strandberg TE, Pitkala K, Eerola J, Tilvis R, Tienari PJ. Interaction of herpesviridae, APOE gene, and education in cognitive impairment. Neurobiol Aging 2005;26:1001-4. https://doi.org/10.1016/j.neurobiolaging.2004.09.008.

[32] Miklossy J, Khalili K, Gern L, Ericson RL, Darekar P, Bolle L, et al. Borrelia burgdorferi persists in the brain in chronic lyme neuroborreliosis and may be associated with Alzheimer disease. J Alzheimers Dis JAD 2004;6:639-49; discussion 673-681. https://doi.org/10.3233/jad-2004-6608.

[33] Herrera-Landero A, Amaya-Sánchez LE, d'Hyver de las-Deses C, Solórzano-Santos F, Gordillo-Pérez MG. Borrelia burgdorferi as a risk factor for Alzheimer's dementia and mild cognitive impairment. Eur Geriatr Med 2019;10:493-500. https://doi.org/10.1007/s41999-018-0153-0.

[34] Westman G, Berglund D, Widén J, Ingelsson M, Korsgren O, Lannfelt L, et al. Increased Inflammatory Response in Cytomegalovirus Seropositive Patients with Alzheimer's Disease. PLoS ONE 2014;9:e96779. https://doi.org/10.1371/journal.pone.0096779. 
[35] Lurain NS, Hanson BA, Martinson J, Leurgans SE, Landay AL, Bennett DA, et al. Virological and immunological characteristics of human cytomegalovirus infection associated with Alzheimer disease. J Infect Dis 2013;208:564-72. https://doi.org/10.1093/infdis/jit210.

[36] Itzhaki RF, Klapper P. Cytomegalovirus: An Improbable Cause of Alzheimer Disease. J Infect Dis 2014;209:972-3. https://doi.org/10.1093/infdis/jit665. 